\title{
"Its Genetic Code is New". Exploring Posthumanism in Zadie Smith's White Teeth
}

\section{Ayman Ibrahim Al-Halfawi}

\begin{abstract}
This paper discusses "Posthumanism" via examining the relation between technology and literature with a particular reference to the works of Katherine Hayles and Cary Wolfe. This paper is divided into two main parts. The first part tends to be an introductory theoretical one. It begins by surveying the history and development of the term 'Posthumanism', especially in literary studies. This part, also, highlights the remarkable role of posthumanist thinkers and critics whose works lead to the rise of digital or computational literature. The second part focuses on the effects of technology on literature. This part of the paper provides a comprehensive analysis of Zadie Smith's novel White Teeth in the light of posthumanism.
\end{abstract}

Keywords:

Posthumanism, technology, literature, Zadie Smith, White Teeth.

The main objective of this paper is to examine the effect of technology on the literary text. It focuses on the writer's reflection of using the advanced technological and biological innovations in the novel. To achieve this aim, the paper attempts to provide an analysis of Zadie Smith's White Teeth (2000) as a posthuman text.

The present research aims to provide a theoretical framework that identifies posthumanism and how it becomes a pivotal issue in modern literary studies in general, and in White Teeth in particular. Furthermore, the present study aims to trace the important aspects of Smith's reflection of modern technological and biological dimensions in the selected novel.

Within the framework of Katherine Hayles' and Cary Wolfe's posthumanist theories, this paper focuses on posthumanism as reflected in Zadie Smith's remarkable novel White Teeth (2000). Accordingly, the study is conducted as an attempt to examine and analyze the development of posthumanism in the literary field focusing on Smith's White Teeth. This study is expected to reveal the relationship between technology and literature and how this relation is reflected in Smith's novel.

Technology and its influence on humanity have become inevitable. In the field of literature, the effect of advanced technology is one of the most important themes in the fictional works. The application of scientific knowledge in fiction is greatly noticeable. Although technological applications are designed to make our life easier and more 
comfortable, some writers feel uneasy about technology. Over the last two decades, the concept of 'Posthumanism' has grown within literary studies to handle the relationship between technology and literature.

In the twentieth century, there is a great shift in the general attitudes toward technology. Technology is no more controlled by humans. Instead, technology becomes able to mimic the human. Thus, the human body becomes like a model for technology, not simply the controller and director of it. As science develops, there is the possibility to create clones, cyborgs, and posthumans. These scientific and technological developments allow us to re-raise questions about what it means to be human.

This paper investigates how the concept of Posthumanism has been developed. It highlights the contribution of the famous thinkers who have defined and theorized Posthumanism. Equally important, the paper explores how one could read the history of Posthumanism.

One of the various notably attempts to characterize Posthumanism has been made by the well-known theorist Francis Fukuyama. Fukuyama has shaped and attributed to the concept's historical development. His Our Posthuman Future: Consequences of the Biotechnology Revolution (2002) reflects a specific interest in emerging cultures of enhancement technology. Fukuyama was a member of the United States President's Council on Bioethics. His analysis of a future where human biotechnological enhancement is important leads to framing the concept of "Posthumanism". However, the concept of "Posthumanism" is negatively advanced because it means the absence of humanism, the transgression of moral boundaries and synonymous with lack of humanism. Moreover, Fukuyama uses the concept to warn about a future with no ethical distinction between therapy and enhancement. In his view, there are some challenges associated with becoming 'Posthuman' because this is greatly connected with inevitable commercialization of life that it will imply. Thus, Fukuyama's 'Posthumanism' arises out of a concern for a political process in a world where the moral force of human rights becomes greatly connected to cybernetic or transgenic species and the disputes about the ownership of DNA. Yet, Fukuyama manages to advance our understanding of Posthumanism.

Fukuyama, actually, is concerned with medical enhancements generally and politics specifically. He considers the ethics of biotechnology as greatly connected to the political economy of scientific 


\section{Ayman Ibrahim Al-Halfawi}

research. Indeed, Fukuyama is concerned that a commercial model of biotechnology will overwhelm an ethics based on humanitarian concerns and that this predicts a posthuman future:

Human nature shapes and constrains the possible kinds of political regimes, so a technology powerful enough to reshape what we are will have possibly malign consequences for liberal democracy and the nature of politics itself. (7)

To sum up, Fukuyama's 'Posthumanism' begins with an analysis of political history and a projection of its future within a biotechnological world. He argues that a conceptualization of the human is crucial to the society. Thus, for Fukuyama, the concept of Posthumanism is invoked and imagined rather than characterized by his analysis. His use of the word 'posthumanism' is expected to do the work of establishing what is immoral about human enhancement.

Another recent posthumanist thinker who describes Posthumanism as technological culture is Robert Pepperell. Pepperell, (1995-2003), tackles Posthumanism as a form of anti-humanism, which is re-shaped by modern science. For Pepperell, Posthumanism is characterized by the absence of humanism. He declares:

Humans have imagined for a long time that the ability to develop and control technology was one of the defining characteristics of our condition, something that assured us of our superiority over other animals and our unique status in the world. Ironically, this sense of superiority and uniqueness is being challenged by the very technologies we are now seeking to create, and it seems the balance of dominance between human and machine is slowly shifting. (3)

However, his notion of Posthumanism as "the end of... belief in the infallibility of human power and the arrogant belief in our superiority and uniqueness"(171), is gradually changed when Pepperell comes to discuss posthumanism as if it were a progressive concept focusing largely on using technology to achieve greater productivity in the society. Unlike Fukuyama, Pepperell's Posthumanism involves embracing human enhancement in a way that rejects traditional technological determinism.

Further developments in the field of 'posthumanism' are made by the professor of English literature Cary Wolfe. Wolfe's works combine aspects from technological theory and materials from animal studies. In his 2003 book Animal Rites, Wolfe tries to criticize humanism seeking 
new ways for cultural analysis beyond the scope of such humanism. In his book What is Posthumanism? (2010), Wolf seeks to undermine the dominant belief that humans are superior to other life forms and intelligences. He reveals that posthumanism represents the decentering of the human by its imbrications in technical, medical, informatic, and economic networks. According to Wolfe, posthumanism tries to:

comprehend what amounts to a new reality: that the human occupies a new place in the universe, a universe now populated by what I am prepared to call nonhuman subjects. And this is why, to me, posthumanism means not the triumphal surpassing or unmasking of something but an increase in the vigilance, responsibility, and humility that accompany living in a world so newly, and differently, inhabited. (What is Posthumanism? 47)

Wolfe starts by offering a historical overview of the origins of posthumanist thought in order to reveal how a posthumanist analysis of culture should be. He argues that the term 'posthumanism' seems to have appeared in contemporary critical discourse in the humanities and social sciences during the mid-1990s. However, it can go further back to the 1960s in Foucault's works. Unlike Foucault, Wolfe believes that the human should not be the yardstick by which all other creatures are measured.

In addition, Wolfe reveals that the development of the term 'Posthumanism' is greatly connected to the Macy Conferences on Cybernetics (1946-1953). He argues that the conferences are very significant for inspiring the cybernetics-based systems theory and Information systems theory. As a result, the human brain was reconsidered as an information-processing system that works in a similar way to the computer and the intelligent machines.

Wolfe, moreover, announces that writings on animals and their exploitation are not enough to minimize the superior status of the humans. Further, he declares that in order to be truly posthumanist, the concept of human subjectivity itself needs to be undermined and transformed in a way that does not privilege the human any more. Wolfe's posthumanist perspective calls for a conception of viewing the human subject not as a singular individual, but as a system related to the all surrounding environment. 
Katherine Hayles is another important name in the field of posthumanism. In her famous book 'How We Became Posthuman?' (1999), she discusses the implications of translating bodies into information. In this book, Hayles writes: "The purpose of this book... how information lost its body, how the cyborg was constructed in the postwar years as technological artifact and cultural icon, and how the human became the posthuman"(291).

The cyborg is derived form of "cybernetic organism". According to Oxford English Dictionary, cybernetics is "the theory or study of communication and control in living organisms or machines" (1989). Cybernetics, as a communication theory, has reshaped the interaction of the elements within the set (organism or combination of organismelements) such that they disrupt existing structures. Hayles declares that "cybernetics was born... as a way to maximize human potential in a world that is in essence chaotic and unpredictable"(How We Became Posthuman? 291).

Moreover, Hayles explains how the body's boundaries have been compromised and that our modern technological world is dominated by a desire to erase bodily burdens and to transform the body into information. Hayles' posthumanist perspective is characterized by loss of subjectivity because of losing the boundaries of the bodies. Hayles traces the possible tensions between humanism and posthumanism. She explains that:

the posthuman is likely to be seen as antihuman because it envisions the conscious mind as a small subsystem running its program of self-construction and self-assurance while remaining ignorant of the actual dynamics of complex systems. But the posthuman does not really mean the end of humanity. It signals instead the end of a certain conception of the human, a conception that may have applied, at best, to that fraction of humanity who had the wealth, power, and leisure to conceptualize themselves as autonomous beings exercising their will through individual agency and choice. (How We Became Posthuman? 286)

In her critical study My Mother Was a Computer: Digital Subjects and Literary Texts (2005), Hayles tries to re-examine the relationship between human beings, computers and their relation with the universe. Specifically speaking, Hayles, in this work, is concerned with the relationship between language and code. She argues that the rapid progress of code-making computational technologies in all areas of life is urgently needed. Accordingly, there is a close relationship between literary works and informatics codes. Her work celebrates the emergence 
of new computerized forms of literary texts. Hayles argues that the rise of digital media allows us to re-understand the literary works because of the emergence of a new computer-based literary text, hypertext and technotext.

In her works, Hayles tries to apply cyborg theory to the relations between humans and machines. She explains that when a human subject participates in submitting a textual digital entity, the texts are transformed into hybrid entities that cannot be thought without the role of the digital machine (computer) that produces them. Thus, there is a close relation between technology and literature and Hayles declares that "Contemporary literature is computational" (My Mother Was a Computer 122). She thinks that Posthumanism is, greatly, focused on how technology can change the so-called human subjectivity. Hayles declares that human-machine interactions are "An essential component of coming to terms with the ethical implications of intelligent machines is recognizing the mutuality of our interactions with them, the complex dynamics through which they create us even as we create them" (How We Became Posthuman? 243).

Most importantly, Hayles believes in the importance of literary narratives in portraying the scientific and technological progress. She declares that literary texts are more effective than scientific texts in tackling cybernetic technologies. That is why she depends on narratives in her book 'How We Became Posthuman?'. In this respect, she writes:

A second way to think about the organization of How We Became Posthuman is narratively...as through the narrative strands about the (lost) body of information, the cyborg body, and the posthuman body. Here the literary texts play a central role, for they display the passageways that enabled stories coming out of narrowly focused scientific theories to circulate more widely through the body politic...the literary texts range across a spectrum of issues that the scientific texts only fitfully illuminate, including the ethical and cultural implications of cybernetic technologies. (21)

In her account of the scientific developments, Hayles highlights the role of narrative in approaching the posthuman as a technical- cultural concept. Consequently, the reality of the interaction between the human and the inhuman, or the posthuman, can be effectively reflected through narratives. Hayles reveals: 
In this regard, the literary texts do more than explore the cultural implications of scientific theories and technological artifacts. Embedding ideas and artifacts in the situated specificities of narrative, the literary texts give these ideas and artifacts a local habitation and a name through discursive formulations whose effects are specific to that textual body. (How We Became Posthuman? 22)

Accordingly, human relations with posthuman biotechnologies take a number of forms, including fictional representations of those relationships. Sometimes, technology is a primary component of the narrative and may be a source of tension for some human characters in the narrative. Sometimes, technology is simply a part of the background of a realist narrative that plays no role in the development of the plot. Sometimes, characters, whether humans or posthumans, try to manage using technology in their lives. Equally important, the characters are, sometimes, created by technology within the narrative and this is reflected in Zadie Smith's White Teeth.

Zadie Smith was born on 25 October 1975. She is an English novelist, essayist, and short story writer. She was born in London to a Jamaican mother and an English father. Smith studied English literature at Cambridge. She completed her first novel, White Teeth, while still at Cambridge and published it after graduation in 2000. In 2002, Smith published The Autograph Man, which follows the fortunes of a Jewish-Chinese purveyor of autographs. On Beauty (2005) was Smith's third novel, and once again focuses on the immigrant experience, this time of a mixed-race British-American family living in the U.S. In 2009, Smith published Changing My Mind, a collection of previously published essays largely about writing and reading. White Teeth was nominated for several Prizes for fiction occupying an interesting place among the popular literary works.

Smith's White Teeth focuses on the biological plurality of the British society by presenting three families of different genetic and ethnic origins: one Anglo-Jamaican (the Jones), another Bangladeshi (the Iqbals), and a third one White-Jewish (the Chalfens). It discusses the consequences that take place when these different families interact with each other. The first family is the Jones consisting of a white British father Archie, his Jamaican wife Clara and their "HalfJamaican. Half English" daughter Irie. The second family is the 
Iqbals. It is an immigrant Bangladeshi family with an Islamic background which consists of Samad and his wife Alsana who are first-generation immigrants from Bangladesh to London. They have British-born twins called Magid and Millat. The third family is the Chalfens. They are a white, intellectual middle-class family with a Jewish- catholic background. They have four children and this family represents Englishness in the novel.

White Teeth is one of the most interesting novels that highlight the role of technology and science. Smith considers how a community of humans can be distinguished from the posthumans. According to Hayles, posthuman figures or beings are characterized as a "union of the human with the intelligent machine" (How We Became Posthuman 2). They are always differentiated from the human, sometimes in degree and sometimes in kind. Thus, the role of the narrative is to represent a means of defining and constructing the posthuman as well as redefining the human.

The existence of the Chalfens in the novel sheds light on the role of technological and scientific development in the novel. This is, mainly, reflected in the novel through the depiction of a genetically engineered mouse called the Future Mouse $\odot$, an experiment conducted by Marcus Chalfen to develop the field of cancer research. Marcus Chalfen is a scientist who is greatly interested in biology and genetic engineering.

Marcus, also, wrote a book entitled Chimeric Mice as a biological study and was very impressed by it. Marcus produced mice that did exactly what he wanted them to do. That is to say, their genes did exactly what he scientifically prepared them to do. Irie spends more time with Marcus because she is interested in his studies. They talk about his biological works, especially those related to DNA. Marcus focuses on genetically engineering the big project of the Future Mouse $\odot$. He explains to Irie

embryo cells are all very well, they help us understand the genetic elements that may contribute to cancer... And this mouse is a unique mouse, Irie. I plant a cancer and a cancer turns up precisely when I expect it... Its genetic code is new. New breed. (Smith 282)

When Marcus wrote his book Time Bombs and Body Clocks: Adventures in Our Genetic Future, some people think the book is weird and somewhat scary because they don't like the idea of genetic engineering worrying about the idea of removing "undesirable qualities" from animals' genes. However, Marcus sees it differently. He believes 


\section{Ayman Ibrahim Al-Halfawi}

that he is working to determine the future of cancer, not the future of the mouse. Marcus thinks about everything in terms of genetics. Marcus believes that science is the only way by which we can control the world. He declares "I'm interested in science... the study of isolated breeds of transgenic animals sheds crucial light on the random... One could program every step in the development of an organism... You eliminate the random, you rule the world"(283).

However, people's attitudes towards technology and science differ and this is clear in the characters' attitudes towards Marcus's work in the novel. Smith portrays some characters as being afraid of Marcus's genetic work. On the one hand, although his genetic work with mice is important, it raises objections from KEVIN, a religious organization, and FATE, an animal rights organization. Some characters in the novel who are driven by religion believe that Marcus's genetic and technological work is some sort of materialism that can harm the human beings.

On the other hand, some characters are admirers of Marcus's genetic work believing in the importance of technology and science like Irie Jones. Irie spends a lot of time in Marcus's office reading his genetic works trying to learn from them. She frequently reads his press release to journalists about the launch of the Future Mouse $(0)$ and admires it so much. She reads "Professor Marcus Chalfen, writer, celebrated scientist, and leading figure of a group of research geneticists... intend to "launch" his latest "design" in a public space; to increase understanding of transgenics"(356). Irie announces to the public that a Future Mouse $\odot$ will be put on display at the Perret Institute in London and will remain on display for exactly seven years because its lifespan has been programmed to live exactly seven years.

The novel highlights the friendship of the Jones and the Iqbals. The characters in this novel, especially the Iqbals, have a cultural identity crisis caused by hybridization. The first generation immigrants exemplified in Archie, Clara, Samad and Alsana are presented as upholding to their original biological and cultural roots. However, the second generation characters born and brought up in England exemplified in Irie, Magid and Millat have less belonging to these roots. In this sense, Zadie Smith tackles the concept of hybridity through the interactions between these culturally-mixed characters. The increasing number of immigrants to London makes it a hybrid society depicted by Homi Bhabha as: "It is the city that the migrants, the minorities, the diaspora come to change the history of the nation...It is the city which provides the 
space in which emergent identifications and new social movements of the people are played out" (243).

The novel provides a complex narrative of relationships between these three families. Samad Iqbal and his wife Alsana are trying to raise their twin sons, Magid and Millat, in Willesden where they live. Samad's attempts to provide his sons with a sense of their heritage fail. The son he sends back to Bangladesh, Magid, comes back as an Englishman, while the son who stays joins a radical Islamist group, the Keepers of the Eternal and Victorious Islamic Nation, KEVIN .Thus, Smith adopts an ironic tone in presenting the family's desire to keep their national identity and its refusal of hybridity. Magid's Bengali roots seem to have diminished, yet he has developed significant faith in the sciences of England. He admires the genetic research of Marcus Chalfen and his Future Mouse. Being disappointed, Samad acknowledges that Magid becomes "More English than the English"(336).

Unlike their father, Samad's sons accept the western environment in which they live. It is clear that the English culture strongly affects the Iqbals. They can neither protect their national biological and cultural roots, nor completely accept the English ones. Zadie Smith describes what happens to the Iqbals as a "trauma". She reflects the tragedy of the Iqbals by saying:

Because immigrants have always been particularly prone to repetition- it's something to do with that experience of moving from West to East or East to West or from island to island. Even when you arrive, you're still going back and forth; your children are going round and round... and this is the tragedy of the Iqbqlsthey can't help but reenact the dash they once made from one land to another, from one faith to another .(135-136)

Gradually, Samad realizes the fact that he is not a biologically-pure person, but he becomes a hybrid one. He, moreover, cannot decide to which country he belongs. He confesses such a confusing fact to his sons' teacher: "I am having difficulties myself- we are all having difficulties in this country, this country which is new to us and old to us at the same time. We are divided people" (149). Here, Samad confesses that he becomes a hybrid person divided between two different cultures feeling to be part of both cultures at once. Thus, the hybridization process of the Iqbals becomes evident though Samad acknowledges that the Iqbals cannot become completely English and still different in one way or another: "We are split people. For myself, half of me wishes to sit quietly 
with my leg crossed, letting the things that are beyond my control wash over me. But the other half wants to fight the holy war.... but I think, in the end, your past is not my past and your truth is not my truth and your solution- it is not my solution"(149-150). Samad, once more, tries to restore his original biological and cultural roots. For Samad "culture led to roots, and these were good, these were untainted principles... roots were roots and roots were good" (161). Now, Samad believes that he has two choices: he can either send his sons back to India (to his original root) or he can let his sons become hybrids. As a result, the idea of original roots for Samad seems to be problematic.

Smith's continuous shedding light on posthumanism becomes clear when Alsana depends on the internet to know her original roots. Alsana looks up the origin of the word "Bengali" in an encyclopedia and discovers that most Bengalis are descended from Indo-Aryans. Alsana triumphantly declares that she is Western after all. She reads loudly: "the vast majority of Bangladesh's inhabitants are Bengalis, who are largely descended from Indo- Aryans who began to migrate into the country from the west thousands of years ago and who mixed within Bengal with indigenous groups of various racial stocks"(196). After reading the encyclopedia, Alsana declares that pure races are just an imaginary tale: "you go back and back and back and it's all still easier to find the correct Hoover bag than to find one pure person, one pure faith, on the globe. Do you think anybody is English? Really English? It's a fairy tale!"(196). Alsana asserts that purity in any shape is impossible to be achieved.

The posthumanist panorama in White Teeth becomes more clear when the narrator describes the 20th century's hybridity resulting in biologically hybrid children whose first and last names clash. The narrator declares:

This has been the century of strangers, brown, yellow, and white. This has been the century of the great immigrant experiment ... children with first and last names on a direct collision course ... you can find best friends Sita and Sharon, constantly mistakes for each other because Sita is white ... and Sharon is Pakistani.(271)

Such a biologically mixed environment highlights Alsana's view that "pure people" can be merely a myth.

Irie Jones, in contrast, represents a good example of the hybrid human. Irie is a typical hybrid girl combining the features of both the English and the Jamaican roots of her parents. Frequently, Irie is trying to 
merge in the English environment trying to change her inherited genetic features; she has a strong "intent upon transformation, intent upon fighting her genes" (228). Asked by an English woman about her identity, Irie declares that she is a product of mixture: "Half Jamaican. Half English" (228).

The existence of the Chalfens in the novel sheds light on Smith's reflection of posthumanism. The family members, especially the parents, appear to be extremely peculiar. The parents' need for determination and control, their obsession with genes and their superior self-perception, cause the effect that the children of the family distance themselves more and more from other races. The parents are trying to preserve their family's so-called pure English roots.

Ironically enough, Smith reveals that the Chalfens, who represent Pure White Englishness in the novel, are revealed to have immigrant hybrid roots. It finally becomes evident that the Chalfens are not the real embodiments of biological and genetic purity in the novel. Stuart Hall, in "The Multi-Cultural Question" (2000), has pointed out that:

The so-called homogeneity of 'Britishness' as a national culture has been considerably exaggerated. It was always contested by the Scots, Welsh and Irish, challenged by rival local and regional allegiances, and cross-cut by class, gender, and generation. There have always been many different ways of being 'British.' (217)

Smith reveals that Marcus Chalfen represents a part of the Jewish diaspora and his roots lie in Poland. This fact about the Chalfens indicates that even the most seemingly pure English family in the novel is not, in reality, fully English. Thus, Smith indicates that even the most presumed English family in the novel is not fully genetically pure and turns out to be a hybrid in a way or another.

What a posthumanist reading of White Teeth reveals is the necessity of genetic, racial and cultural hybridity through emphasizing the necessity of biological merging and combining a variety of genetic roots. Smith criticizes the migrant's desire to adhere to fixed pure genetic and racial origins. As first generation immigrants, Samad and Alsana have strong connections to Jamaica and Bangladesh, and this affects the formulation of their identity. Instead of embodying identities based on their genetic origins, Samad's and Alsana's identities are tied to their position as immigrants and as hybrids within the English society. However, hybridity 


\section{Ayman Ibrahim Al-Halfawi}

is part of the life of the novel's second generation represented in Irie, Magid and Millat. The second generation's identities and roots blend many aspects of the Western culture. The hybrid experience of the second generation is a result of inheriting their family's original genetic roots, and merging with the hybrid environment of England because it is the county of their birth and bringing up. As a result, White Teeth reveals genetic purity to be a myth via posthumanism in the novel.

In conclusion, depending on Hayles' works, White Teeth embodies how posthumanism can be effectively reflected in a literary work. Smith wants to end the fears about the future of posthumans taking the Future Mouse $(\odot$ as a strong example. Even though some people, strongly, refuse Marcus's genetically developed mouse, it has not died at the end. Instead, the mouse manages to create a new future for itself, and this calls for an optimistic outlook towards the future of Posthumanism. Smith's interest in the role of technology can be summarized in the following quotation:

The FutureMouse $\odot$ experiment offers the public a unique opportunity to see a life and death in "close-up." The opportunity to witness for themselves a technology that might yet slow the progress of a disease, control the process of aging, and eliminate genetic defect. The FutureMouse $\odot$ holds out the tantalizing promise of a new phase in human history, where we are not victims of the random but instead directors and arbitrators of our own fate. (357)

The importance of this scene lies in the fact that it is the last one in the novel and all the characters come together in the same place to witness the display of the genetic mouse. Despite some attempts for making the mouse escape, Archie Jones follows it as if it were his son saying "Go on my Son!" (448), and these are the last words in the novel. These final words emphasize optimism towards the future of genetic and technological development. Even though the FutureMouse $\odot$ death has already coded into its genetic structure to die after a certain period of time, it hasn't died and managed to escape having another chance to life again.

White Teeth does not only describe the role of cybernetic technologies, but also explores their impact on the public. In this sense, Smith sheds light on the importance of genetic engineering and the creation of artificial beings that captures the attention of some humans, like Archie in the above mentioned quotation, ending the raised fears by some characters in the novel. Thus, Smith participates in removing the 
"Its Genetic Code is New". Exploring Posthumanism in Zadie Smith's White Teeth

public fears about genetic development through her representation of the effective qualities of genetics in the novel.

Smith's White Teeth succeeds in reflecting Katherine Hayles' posthumanist vision. Throughout her novel, Smith stresses Hayles' attitude towards the relation and boundaries between technology and literature by proving that a comprehensive description of technology and science can be presented through narrative or fictional forms. That is to say, the communication of science and technology to the public readers relies, largely, on the use of narrative works and Smith manages to use White Teeth as a means to prove this. 


\section{Ayman Ibrahim Al-Halfawi}

\section{Works Cited}

Bhabha, Homi K. The Location of Culture. London: Routledge, 2004. Print.

"Cybernetics." Oxford English Dictionary. 2nd ed. 1989. Print.

Fukuyama, Francis. Our Posthuman Future: Consequences of the Biotechnology Revolution. London: Profile Books, 2002. Print.

Hall, Stuart. "The Multicultural Question". Un/Settled Multiculturalism: Diaspora. Entanglements. Transruptions. Ed. Bamor Hesse. London: ZED Books, 2000.209-41. Print.

Hayles, Katherine. How We Became Posthuman: Virtual Bodies in Cybernetics, Literature, and Informatics. Chicago and London: University of Chicago Press, 1999. Print.

---. My Mother Was A Computer: Digital Subjects and Literary Texts. Chicago and London: University of Chicago Press, 2005. Print.

Pepperell, Robert. The Posthuman Condition: Consciousness Beyond the Brain, 3rd Edition. Bristol: Intellect Books, 1995/2003. Print.

Smith, Zadie. White Teeth. New York: Vintage International Books, 2001. Print.

Squires, Claire. Zadie Smith's White Teeth. New York: Continuum, 2002. Print.

Tew, Philip (ed). Reading Zadie Smith: The First Decade and Beyond. London: Bloomsbury, 2013. Print.

Wolfe, Cary. Animal Rites: American Culture, the Discourse of Species, and Posthumanist Theory. Chicago and London: University of Chicago Press, 2003. Print.

---. What is Posthumanism? Minneapolis: University of Minnesota Press, 2010. Print. 